\title{
Service Atonement toward the Service Dissonance and Customer Switching
}

\author{
Suwignyo Rahman and Ibnu Widiyanto
}

\begin{abstract}
The objective of this study is to develop a model of service dissonance management. Variables that affect on the service dissonance are the failure and atonement services. Service dissonance may result in the customer switching. This study applied the Structural Equation Modeling (SEM) with AMOS as the data analysis. The sampling method used was a purposive sampling method, with Customers who ever experienced service failure as the criterion, not the Jamkesmas (health card) holders. There were 260 respondents as the sample of this study. This sample take until 2 month (July August 2013). After examining the normality test and classical assumption, the result showed that the service failure affected on the service dissonance although it was not significantly affected. Service failure also positively affected on the service atonement. Moreover, service atonement positively affected to the service dissonance. However, service dissonance had negative and no significant effect on the costumer switching.
\end{abstract}

Index Terms-Service atonement, service failure, service dissonance, customer switching.

\section{INTRODUCTION}

The service failure in service which is experienced by the customers / service users may be expressed in various ways and attitudes. The negative attitude on what the customers's feel expressed by inviting, panning, and even suing our service products in the public that result on the unnecessary dissonance. The degree of failure and justice achieved may effect on the satisfaction, that lead to the repatronage aim, words from words from mouth to mouth, and the intention to complain [1]. Service dissonance experienced by customers may result in the failure of customers to switch services. the determinants of customers' decisions to switch service providers appear to vary in different countries. The presence and/or introduction of "competition" was (with the exception of Poland) the most frequently identified factor that determined service customer switching. Switching factors were most frequently noted in the following order competition, pricing, core service failure, response to failed service, failed service encounter, inconvenience, and ethical problems [2]. That is why the service failure in service should be took into account and handled appropriately so that the dissonance happened can be well-controlled and have no bad impact on the product/service produced. It needs a service atonement towards service failure on the product/service produced by the service provider.

Manuscript received November 8, 2013; revised January 20, 2014. This study is the self-financed study of these researcers.

The authors are with the Doctoral Programe in Economics, Diponegoro University, Indonesia (e-mail: suwignyo_rahman@yahoo.com, ibnu.widiyanto@undip.ac.id).
Prita Mulya Sari's case who did a Negative Word of Mouth on withholding her child's Laboratory Diagnostic Result by Omni International Hospital by texting on the miling list group some times ago was an example of yet or not fully service failure in service [3]. Service failure in service which is not well-managed by the service provider resulting the dissonance and will harm the service provider's image. It caused The Omni International Hospital got a lot of sneers because of giving a negative respond to the Prita Mulya Sari's demand. The Omni Internasional Hospital's negative response by reporting Prita Mulya Sari's action as a crime based on the ITE Act had made million people gave the hospital a louder sneer through the social media on facebook and twiter. Omni International Hospital felt they had power to stop and give Prita Mulya Sari a lesson, but this action even more harming the Omni International Hospital Image. Among politicians in Indonesian Legislative Assembly, government officials, religious leaders, and communities are sympathetic to Prita Mulya Sari.

This case indicate that the effect of service failure can occur everywhere either on the Hospital held by the public or government. The number of inpatients who do inpatient services and other services in the hospital held by the public or Indonesian government are very large in number.

Some studies showed that the theoretical debate of the research result on the relationship between the service failure in service towards the dissatisfaction showed on service dissonance. This discussion showed that the relationship between service failure in service and the level of dissatisfaction shown in the service dissonance was still debatable by some researchers. On this study, therefore, it attempts to get a clear relationship between the service failure in service and the level of dissatisfaction shown in the service dissonance which can cause costumer switching.

The phenomena discussed above can be seen from some point of views that, on the one hand, some believe that service failure will affect on customer switching. This thing matches with the research finding [2] which state that core service failure can lead to the service switching behaviour and then dissatisfaction, negative word of mouth and search new service. On the other hand, some state that service failure does not always affect to service dissonance and customer switching. This statement is in line with research finding [4] which state that on the majority of respondents still feel satisfied even enjoy greater satisfaction despite the filure of service providers to make effort for the recovery. This means that the quality of service received by customers is good or bad one through customer service failures do not result in the switch. From the arguments above, we can conclude that there are differences in opinion on the influence of customer switching after a service failure. 
This study conducted based on the theoretical contradiction problems of the research result about the service failure in service after failure service that may cause service dissonance and customer switching which is abstracted in the research gap above. This study is different from the research conducted before, because it will explain the elements of service atonement on the service failure in service after service failure that resulting the service dissonance and may cause the costumer switching. Therefore, the research problem stated in this study is: How does the service atonement in service after service failure that resulting service dissonance and prevent the costumer switching?

The purpose of this study is to build a model of service atonement management in reducing the service dissonance in service after failure service that may result in customer switching. The result of this study is expected to provide a variety of contibutions that is not only in the science development for academics, but also in the operational contibutions for practitioners.

\section{Hypothesis OF SERVICE FAILURE DEVELOPMENT}

The result of study [5] shows that support the hypothesis The greater the customers' perception that a service failure is due to lack of preferential treatment, the greater their dissatisfaction after the service failure. The main aim of the current research was to determine whether or not lack of preferential treatment (perceived as a cause of the failure) has a positive impact on dissatisfaction following a service failure, after accounting for the effects of stability and controllability attributions. Attribution of controllability after a service failure has a positive impact on customers' dissatisfaction after the service failure. The intensity of negative emotions experienced after a service failure has a positive impact on customers' dissatisfaction after the service failure. The intensity of negative emotions mediates the effect of perception of lack of preferential treatmen and attribution of controllability, on customers' dissatisfaction after the failure.

Another study [6] finding that an Internet user's encounter with a service failure did not influence his/her attribution for failure. The findings show that respondents' subjective views of their previous encounters with a service incident have no significant effect on their attribution of assigning blame for the service failure. This shows that the fact that a customer has a service problem in the past might not affect how the customer assigns blame in other service situations. It is possible that other factors are involved in how customers assign blame to the service providers, the service process, technology, themselves, and/or a combination. Based on the explanation above, the hypothesis of problem formulated in the other part as follows: H1 = Service failure in service affects on the service dissonance.

\section{HyPOTHESIS OF SERVICE AtONOMENT DEVElOPMENT}

This service atonement becomes the efforts of compensation, penance, and link to connect the relationship between service provider and customer can be well-established and customer does not move to other providers. Based on the research [5] can be concluded that while the length of the relationship can be used to evaluate the effect of service failure between the US passenger and the airlines and their willingness to recommend the airlines, the effect of failure service on the South African passenger needed to be more considered by taking the passangers' satisfaction rate in line with the airlines's atonement service.

Results other studies that found that the service atonement can influence the consumers' satisfaction stronger to the consumers with a high complaint/attitude toward complaining (ATC) showed the role of ATC moderation [1]. This research conducted a study that aimed to investigate, in the context of service failure and its atonement, how the customer's satisfaction is influenced by the degree of problem and company's respond, how the satisfaction affects to the repatronage intention from mouth to mouth and the complaint intention, and how the consumer's behavior towards the moderation of complaint relationship. Based on the description above, the hypothesis of problem formulated in the other part as follows: H2 = Service Failure can affect on the service atonement.

\section{HyPOTHESIS OF SERVICE DiSSONANCE DEVELOPMENT}

The dissonance of service failure becomes a problem if there is no effort to do the service atonement as described above. Based on the results of the study [7] showed that the cognitive dissonance theory proposes when a person holds two psychologically inconsistent cognitions (ideas and beliefs), the dissonance appears. The service dissonance can be handled quickly and appropriately if there is a quick atonement done by the service provider. Understanding the dissonance of the service failure is very relevant in this research. This study [7] conducted a study which presents the progress of the cognitive dissonance theory history.

Another study [8] stated that the atonement strategy offset the negative impact of negative emotion (dissonance) on the customers' satisfaction and the compensation strategy is more efficient if it is offered quickly. Based on the description above, the hypothesis of the problem formulated in the other part as follows: H3 = Service Atonement can affect on the service dissonance.

\section{HiPOTHESIS OF CUSTOMER SWITCHING DEVELOPMENT}

There is a positive relationship between unfavorable good service quality and customers switching banks [9]. The primary objective of this study is to identify the factors that influence customers switching and determine the most important and least important factor that influence customers switching behavior. And then, another study [10] found out that the quality of the offered banking products and services in combination with the bank's brand name have a positive effect in the decrease of switching behaviour while demographical characteristics, such as gender and educational level have a limited impact.

In other side, cognitive dissonance can influence customer 
switching. The willingness of a dissonant individual to accept the new cognition increases with the elapse of time from the time of occurrence of the cognitive dissonance [11]. The study also unveils that, for a typical purchase, the degree of cognitive dissonance felt by more involved purchasers is less than that felt by less involved purchasers.

This finding is reinforced by the result of research which state that the research finding on Perceived service quality indirect effect on switching intention but satisfaction emerged as the strongest factor which influences switching barriers [12]. In this research, Employees' responses to service failures, reasonable prices and core services up to expectations significantly influence switching intentions. Also, higher switching barriers, lower will be the customer switching intentions. For high switching barrier group, satisfaction loyalty link will be weak. Higher the quality, higher the satisfaction, higher will be the loyalty. Higher the quality, higher the satisfaction, weaker will be the switching intentions. Higher the quality, higher the satisfaction, higher will be the switching barrier.

Based on the description above, the hypothesis of problem formulated in the other part as follows: H3 = Service dissonance can affect the customer switching.

\section{RESEARCH DESIGN AND EMPIRICAL RESEARCH MODEL}

Based on the classification, this study belongs to an explanatory research because this study intends to explain the causal relation between variables through a hypothesis testing. In this part of this research, it is explained how the Empirical Research Model is. In short, Empirical Research Model can be seen in the image below Fig. 1.

In an empirical research model, it examines how the service failure influences service dissonance. Furthermore, in reducing service dissonance, it tests the influence of service failure towards the service atonement. Then, it will also be tested if the service atonement can affect to the service dissonance. Finally, the service dissonance is tested whether it can affect the customer switching.

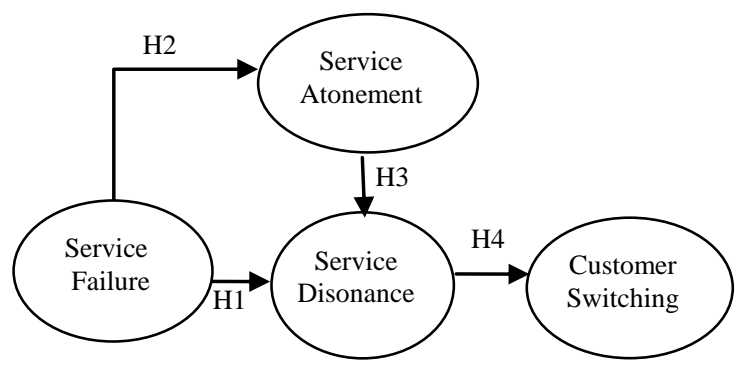

Fig. 1. Empirical research model.

This study applied the Structural Equation Modeling (SEM) with AMOS as the data analysis [13]. The sampling method used was a purposive sampling method, with Customers who ever experienced service failure as the criterion, not the Jamkesmas (health card) holders. There were 260 respondents as the sample of this study. This sample take until 2 month (July - August 2013). The Measurement used in this study is measurement of data interval. Each indicator measured using a scale with 10 possible answers, where the lowest respond is given a score of 1 (very Disagree) and the highest respond is given a score of 10 (Very Agree).

\section{A. Sample Description}

Based on the composition of respondents by frequency of inpatient and outpatient care shows that the number of outpatient respondents are bigger that are as many as 140 people or $53.85 \%$ compared to inpatients as many as 120 people or $46.15 \%$.

\section{B. The Analysis of Structural Equation Modelling (SEM)}

The result of data processing for SEM full analysis model shown in the following Fig. 2.

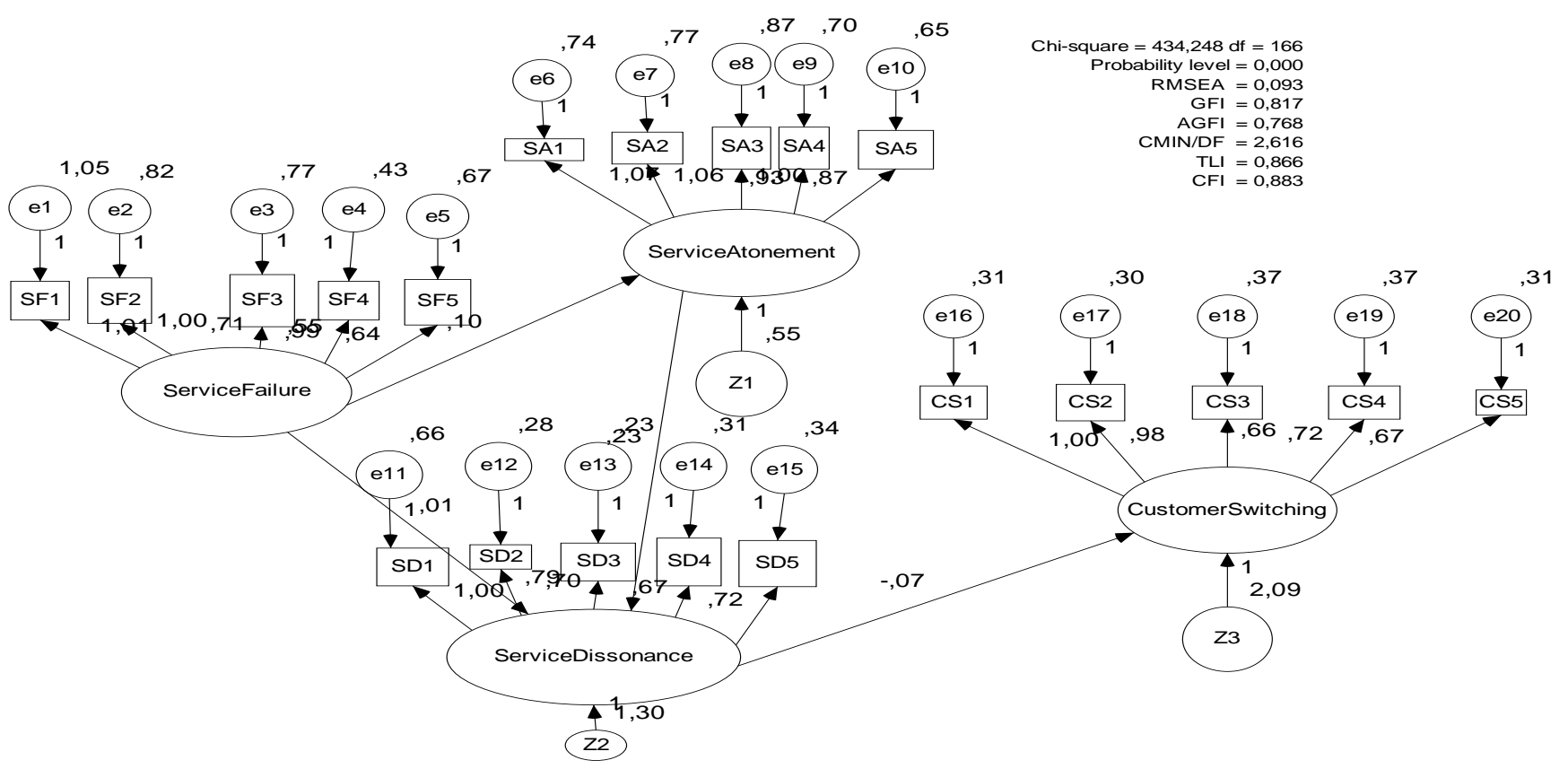

Fig. 2. SEM full analysis model. 
The feasibility test of full SEM models is summarized as the following Table I:

TABLE I: THE RESUlT OF FEASIBILITY TEST OF FULl STRUCTURAL

\begin{tabular}{llll}
\multicolumn{1}{c}{\begin{tabular}{c} 
EQUATION MODEL \\
\multicolumn{1}{c}{ Indeks }
\end{tabular}} & Cut-Off Value & $\begin{array}{c}\text { Result } \\
\text { Analisis }\end{array}$ & $\begin{array}{c}\text { Evaluation } \\
\text { Model }\end{array}$ \\
\hline Chi-Square & $\begin{array}{l}\text { Kecil } \\
(<210.129)\end{array}$ & 434,248 & Fit \\
Probability & $\geq 0.05$ & 0,000 & Fit \\
& & & \\
RMSEA & $\leq 0.08$ & 0,093 & Fit \\
GFI & $\geq 0.90$ & 0,817 & Fit \\
AGFI & $\geq 0.90$ & 0,768 & Fit \\
CMIN/DF & $\leq 2.00$ & 2,616 & Fit \\
TLI & $\geq 0.95$ & 0,866 & Fit \\
CFI & $\geq 0.95$ & 0,883 & Fit
\end{tabular}

Source : Premier data processed, 2013.

The analysis of data processing result showed that the model used is acceptable. The Significance level was 0.000 which indicated a good structural equation model. To calculate the mahalanobis distance based on the chi-square score on the degree of freedom of 25 (number of indicators) at the level of $p<0.001$ is $x_{2}(20,0.001)=45.314$ (based on distribution tables $x_{2}$ ). From the processed data could be concluded that the maximum Mahalanobis distance was 37.124 which was still below the maximum limit of multivariate outlier.

\section{Hypothesis Testing}

The test of 5 hypothesis stated in this research done based on the value of Critical Ratio ( CR ) of a causal relation from the SEM processing result as stated in the following Table II:

TABLE II: REGRESSION WEIGHTS: (GROUP NUMBER 1 - DEFAULT MODEL)

\begin{tabular}{|l|rrrrr|}
\hline & Estimate & S.E. & C.R. & P & Label \\
\hline SA<--- SF &, 105 &, 071 & 1,475 &, 140 & par_10 \\
SD<---SA &, 225 &, 138 & 1,630 &, 103 & par_11 \\
SD<---SF &, 009 &, 099 &, 089 &, 929 & par_13 \\
CS<---SD &,- 066 &, 098 &,- 677 &, 498 & par_12 \\
\hline
\end{tabular}

\section{DISCUSSION}

The results of this study showed that all the tested hypothesis was proven, they were:

$\mathrm{H} 1=$ service failure in service influence service dissonance.

The estimation parameter for testing the effect of the service failure towards the service dissonance showed the positive CR value of 0.089 and with a probability of 0.929 . Both values were obtained and it qualified the requirement of $\mathrm{H} 1$, although the probability was not smaller than 0.05 , so the hypothesis 1 was accepted and $\mathrm{H} 0$ was unaccepted. It meant that there was a significant effect of the service failure towards service dissonance, so the hypothesis $\mathrm{H} 1$ was proved . In conclusion, we can conclude the dimensions of service failure towards service dissonance. This is in line with the findings of research essentially states that core service failure can lead to the service switching behaviour and then dissatisfaction, negative word of mouth and search new service [2].
$\mathrm{H} 2$ = service failure can influence service atonement.

The estimation parameter for testing the effect of the service failure towards the service atonement showed the positive CR value of 1.475 and with a probability of 0.140 . Both values were obtained and it qualified the requirement of $\mathrm{H} 1$, although the probability was not smaller than 0.05 , so the hypothesis 1 was accepted and $\mathrm{H} 0$ was unaccepted. It meant that there was a significant effect of the service failure towards service atonement, so the hypothesis $\mathrm{H} 2$ was proved. Then, we can conclude the dimensions of service failure towards service atonement. It matches with findings of research state that the service atonement becomes the efforts of compensation, penance, and link to connect the relationship between service provider and customer can be well-established and customer does not move to other providers [4].

H3 = service atonement can influence Service Dissonance.

The estimation parameter for testing the effect of atonement service towards the service dissonance showed the positive CR value of 1.630 and with a probability of 0.103 . Both values were obtained and it qualified the requirement of $\mathrm{H} 1$, although the probability was not smaller than 0.05 , so the hypothesis 1 was accepted and $\mathrm{H} 0$ was unaccepted. It meant that there was a significant effect of the atonement service towards service dissonance, so the hypothesis $\mathrm{H} 3$ was proved. As a conclusion, the dimensions of service atonement towards service dissonance. This is in line with the findings of research state that the atonement strategy offset the negative impact of negative emotion (dissonance) on the customers' satisfaction and the compensation strategy is more efficient if it is offered quickly [8].

H4 = Service Dissonance can not influence Customer Switching.

The estimation parameter for testing the effect of the service dissonance towards consumer switching showed the negative CR value of -0.677 and with a probability of 0.498 . Both values were obtained and it did not qualify the requirement of $\mathrm{H} 1$, that the probability was bigger than 0.05 , so the hypothesis 1 was not accepted and H0 was accepted. It meant that there was no significant effect of the service dissonance towards costumer switching, so the hypothesis H4 was not proved. Thus, we can conclude the dimensions of service dissonance had no effects towards the consumer switching. The result was in line with research [12] which state that the research finding on Perceived service quality indirect effect on switching intention. This means that the quality of service received by customers is good or bad one through customer service failures do not result in the switch. It is possible to happen because the patient that has become the customer of one hospital feel that only on that hospital the service given and not in any other hospital.

\section{LIMITATION AND FUTURE RESEARCH}

The limitations of this study occurred because of the following things:

1) In sampling, there were some respondents in these three hospitals that the respondents were only a bit or never experience service dissonance or service failure. Because the hospital did not have exact data on service 
users who have experienced service dissonance service failure. Therefore, the writers conducted the service users with the criteria for those who only experienced service failure. The same thing would be better if in the future research has been devoted to the respondents who had experienced service failure and service dissonance.

2) In the interview with the respondents, in one of the hospital, respondents did not answer freely because there are some hospital officers, who accompanied during the interview. Therefore, for future research, the hospital should give the permission to the author to conduct the research without accompanied by the hospital officers.

The result of the study provides some managerial implication as follows:

1) Hospitals should be able to manage the service failure through the service atonement optimally. Service failures are not managed properly will lead to a boomerang for the hospital, one of them is the high service dissonance and the possibility of consumer switching. Otherwise, failure service that is well-managed give good impact for the hospital.

2) Hospital should reduce the service failure happened in their organizations through professional services in order to avoid dissonance service which will lead to the consumers move to other hospitals.

\section{CONCLUSION}

The result of the study showed that 4 hypotheses are proved, the 3 hypotheses are $\mathrm{H} 1$ = service failure in service influence service dissonance; $\mathrm{H} 2$ = service failure can influence service atonement; H3 = service atonement can influence Service Dissonance. Then, 1 hypotheses that cannot be proved is $\mathrm{H} 4=$ Service Dissonance cannot influence Customer Switching.

\section{REFFERENCES}

[1] C. A. de Matos, C. A. V. Rossi, and R. T. Veiga, "Consumer reaction to service failure and recovery: the moderating role of attitude toward complaining," Brazil Journal of Services Marketing, Emerald Group Publishing Limited, vol. 23, no. 7, pp. 462-475, 2009.

[2] R. Frankel and E. C. M. Sagan, "Service Switching, word of mouth, and new provider search: Five country exploratory study," International Journal of Management and Marketing Research, vol. 6, no. 2, pp. 11-20, 2013.

[3] Indonesian Human Right Watch Report Edition Mei, 2010

[4] T. F. J. Steyn, C. F. de Meyer, and L. R. J. V. Rensburg, "The effect of service failure and recovery on airline-passenger relationships: a comparison between south african and united states airline passengers," Journal of Management Policy and Practice, vol. 12, no. 5, pp. 105-115U, 2011.

[5] C. V. Neira, R. V. Casielles, and V. Iglesias, "Lack of preferential treatment: effects on dissatisfaction after a service failure," Journal of Service Management, Emerald Group Publishing Limited, vol. 21, no. 1, pp. 45-68, 2010.

[6] A. T. Ogungbure, "Failure and recovery: An Opportunity to reconnect and recommit to customers after service failure in the internet-based service encounters," The Journal of American Academy of Business, Cambridge, Troy University, Atlanta Site, Atlanta, GA, vol. 18, no. 1, pp. 25-32, September 2012.

[7] I. Metin and S. M. Camgoz, "The advances in the history of cognitive dissonance theory," International Journal of Humanities and Social Science, vol. 1, no. 6, pp. 131-136, June 2011.

[8] C. V. Neira, R. V. Casielles, and V. Iglesias, "The effects of customer age and recovery strategies in a service failure setting," Journal of
Financial Services Marketing, Macmillan Publishers Ltd. 1363-0539, vol. 15 , no. 1 , pp. 32-48. 2010.

[9] N. U. R. Khan, A. M. Ghouri, U. A. Siddqui, A. Shaikh, and I. Alam, "Determinants analysis of customer switching behavior in private banking sector of Pakistan," Interdisciplinary Journal Of Contemporary Research Business, Institute of Interdisciplinary Business Research, vol. 2, no. 7, pp. 96-110, November 2010.

[10] M. Mavri and G. Ioannou, Customer Switching Behaviour in Greek Banking Services Using Survival Analysis, Management Sciences Laboratory, Emerald Group Publishing Limited, Department of Management Science \& Technology, Athens University of Economics \& Business, Athens, Greece. Managerial Finance, vol. 34, no. 3, 2008, pp. 186-197.

[11] B. P George and M. Edward, "Cognitive Dissonance and Purchase Involvement in the Consumer Behavior Context," The IUP Journal of Marketing Management, vol. VIII, no. 3- 4, pp. 7-24, 2009.

[12] R. D. G. K. Sharma and N. Mahajan, "Exploring customer switching intentions through relationship marketing paradigm," International Journal of Bank Marketing, Emerald Group Publishing Limited, Department of Commerce, University of Jammu, Jammu, India, vol. 30, no. 4, pp. 280-302, 2012.

[13] J. F. Hair and W. C. Black, Multivariat Data Analysis, Sevent Edition. 2010, Pearson Prentice Hall.

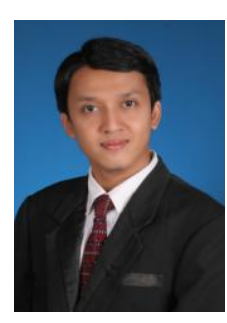

Suwignyo Rahman is a Ph.D. candidate at Doctoral Programe in Economics, Diponegoro University, Indonesia, and got bacheloor and master of management from Diponegoro University, Indonesia. Now, he is a Consultant at CV KRCI and Expert in DPRD (Regional People's Council) of Semarang City. $\mathrm{He}$ is also as a executive director at Strategic Studies and Social Democracy, Indonesia. He's been awarded in several competitions scientific research work are: Top 3 Finalists Researchers in Indonesia Election Young Researchers (PPMI) organized by the Indonesian Institute of Sciences (LIPI) to the field of Social Sciences and Culture on 2006. Research Top 10 Finalists in Competition Winners The World Bank study of Poverty 2004: Making Services Work for the Poor (Poverty Research Competition, The World Bank 2004: Making Services Work For The Poor) on 2005. Winner of Competition works Scientific Bumiputera 2002 Category Students. He has published his article "Independence of Small and Medium Enterprises, Lord of the State itself" in Book "Sued the Nation, Nationalism, Independence and Entrepreneurship" by LP3ES Jakarta, 2003. He has published with UGM and Unila researcher "Dynamics implementation of local regulations of public services in health, labor and natural resources are pro-poor, women and children and other marginalized communities in the province of Lampung and Central Java" at proceeding National Seminar Initiating Formulation and Implementation of Regional Regulation participatory, transparent and accountable by Justice for the Poor, The World Bank. 2006. Also, He has published research paper with Hasan "Implementation of local regulations, case study at PKL Pasar Bulu dan Waru, Semarang City" Journal of Economics and Business University of Wachid Hasyim, 2006. Published research paper with Istiono, W. Abdulrachman, L. Mardiana, "Analysis of Patterns Of Participation and Communication Between The Community and Government In An Effort To Minimize Conflict Development, Journal Litbang Central Java Province, 2009. Also published research paper with Vincent Didiek Ariyanto "Orientation Service Delivery Service Performance of service" at proceeding "National Research Conference on Management VII, 2013, which was held by the Research Center and Case Clearing House - PPM School of Management in collaboration with the University of Sriwijaya Palembang.

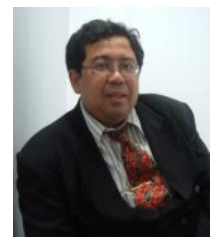

Ibnu Widiyanto is a senior lecturer at Faculty of Economics and Business, Diponegoro University, Indonesia. He obtained the Dr. in Diponegoro University, Indonesia, and obtained the MA in Acadia University, Canada, and obtained the Ph.D. in Dalhousie University, Canada. He was a deputy director of academic affairs of the master of management program in Diponegoro University, and the assessor for BKD, student counselor, consultant. His professional services is an assessor for BAN PT, editors and reviewer of Journal of Business Strategy, Journal of Indonesia Marketing Science, Journal of Organization and Management Studies, Journal of Management and Entrepreneurship. His research interests is marketing and entrepreneurship. He Publication in Entrepreneurship Development of Economics Students of Diponegoro 
University, the Journal of Organization and Management Studies, January 2010. On Saving Behaviour, the Journal of Entrepreneurial Development, December 2010. On Saving Behaviour: Empirical Evidences, the Journal of Entrepreneurial Development, April 2011. Analysis of the influences of Brand Image, Prceived Quality and Price on Purchase Decision, Diponegoro Journal of Management, 2012 (with K. Tambunan). Study of E-Toll Card Purchase Intention in Semarang, Diponegoro Journal of Management, 2012 (with C. A. Purnama). A Decision Support System of Tea Beverages Outlet
Franchise Selection in Indonesia, proceedings of the International Conference on System Business Competitiveness, 2012. Antecedents of Online Purchase Decision, Diponegoro Journal of Management, 2013 (with S.A. Rahmawati). Study of Brand Loyalty of Commercial Vehicle in Semarang, Diponegoro Journal of Management, 2013 (with B. Sutanza) Study of Innovation of Micro, Small and Medium Enterprises in Semarang, Journal of Management and Entrepreneurship, 2014 (forthcoming). 